\title{
PERSEPSI WISATAWAN TERHADAP AKSESIBILITAS DARI PENELOKAN MENUJU OBJEK WISATA TOYA BUNGKAH KECAMATAN KINTAMANI KABUPATEN BANGLI
}

\author{
I Wayan Agus Slamet \\ I Nyoman Sudiarta \\ I Wayan Suardana \\ Email : agus_slamet91@yahoo.com \\ PS. S1 Industri Perjalanan Wisata \\ Fakultas Pariwisata UNUD
}

\begin{abstract}
The perception of tourist about accessibility from Penelokan village to Toya Bungkah destination" has objective to known the tourist perceptions of accessibility in Toya Bungkah destination. Kinds data used are primary data and secondary data. The data was gain through observations, depth interviews, questionnaires, literature studies, and documentations. Sampling was gain by purposive sampling to option the data of accessibility. The respondents was choose by using quota sampling. Analyzed the perception of tourist by using attitude scale (Likert scale) to measure the results.

The result of the research showed that the tourist perceptions of accessibility to Toya Bungkah were : Condition about access from Penelokan to Toya Bungkah get average score was 3.10 is good enough, Quality of access from Penelokan to Toya Bungkah get average score was 3.20 is good enough, Comfortable of access from Penelokan to Toya Bungkah get average score was 3.14 is good enough, Condition transportasion after arrived from Penelokan to Toya Bungkah get average score was 3,48 is good, View at around access the tourist can see from Penelokan to Toya Bungkah get average score was 4.08 is good, Safety with the path from Penelokan to Toya Bungkah get average score was 3.50 is good, Perception of the tourist about Toya Bungkah get average score was 3.76 is good.
\end{abstract}

Keywords: Perseption and Accessibility.

\section{PENDAHULUAN}

Bali memiliki wilayah yang mempunyai potensi yang luar biasa dilihat dari kebudayan maupun keindahan alam di dalamnya. Salah satu wilayah yang memiliki potensi yang baik dilihat dari kebudayaan maupun keindahan alamnya ialah Kabupaten Bangli yang merupakan salah satu kabupaten di Provinsi Bali yang menyimpan sejumlah potensi seperti keindahan panorama Gunung dan Danau Batur yang terletak di Kecamatan Kintamani.

Kepariwisataan Kabupaten Bangli yang mulai tumbuh dan berkembang menarik wisatawan untuk berkunjung dan menikmati keindahan alamnya. Salah satu objek wisata yang terdapat di Kabupaten Bangli ialah Toya Bungkah

Toya bungkah merupakan daerah tujuan wisata yang sangat potensial untuk di kunjungi oleh wisatawan, namun dalam pengembangan objek atau daya tarik ini masih memiliki keterbatasan dalam aksesibilitas yang masih butuh perhatian dari masyarakat setempat guna memberikan kenyamanan serta keselamatan wisatawan dalam menuju objek wisata Toya Bungkah. Kunjungan wisatawan ke objek wisata Toya Bungkah mengalami penurunan, dari hasil wawancara dengan pihak Pemda Pariwisata bidang bina objek Kabupaten Bangli menyebutkan bahwa dari tahun 2007-2008 
dengan pertumbuhan $1,32 \%$ hal ini di karenakan wisatawan tidak merasa nyaman mengunjungi Toya Bungkah. Pada Tahun 2009 kembali mengalami penurunan dengan pertumbuhan $1,43 \%$ kurangnya promosi dalam pengembangnya, Tahun 2010 mengalami peningkatan dengan pertumbuhan $0,77 \%$ hal ini di karenakan pemda setempat mulai menata Toya Bungkah untuk menjadi objek wisata, kemudian di Tahun 2011 kembali mengalami penurunan dengan pertumbuhan $1,93 \%$ hal ini di karenakan meningkatnya kecelakaan saat melewati aksesibilitas di Toya Bungkah.

Keterbatasan aksesibilitas di Toya Bungkah perlu kiranya diperhatikan dengan mengetahui pendapat wisatawan yang melewati aksebilitas di Toya Bungkah untuk mampu menyimpulkan apakah dengan keterbatasan aksesibilitas di Toya Bungkah wisatawan merasa kurang baik untuk berkunjung ataukah wisatawan merasa bahwa keterbatasan aksesibilitas di Toya Bungkah tidak menghalangi keinginan wisatawan untuk berkunjung ke Toya Bungkah.

Aksesibilitas yang baik memiliki lebih banyak potensi untuk mendatangkan dan meningkatkan jumlah kunjungan wisatawan. Destinasi atau objek wisata akan mampu berkembang bila didukung oleh aksesibilitas yang memadai yaitu mampu dilalui suatu mode transportasi seperti: Mobil, Angkutan Umum, Sepeda Motor, dan lain sebagainya. Oleh karena itu perlu kiranya peneliti membahas mengenai persepsi wisatawan tentang aksesibilitas yang dilaluinya menuju objek wisata Toya Bungkah

\section{TINJAUAN PUSTAKA}

Menurut Salah Wahab dalam Yoeti (1997: 116). Pariwisata adalah suatu aktivitas manusia yang dilakukan secara sadar yang mendapat pelayanan dalam suatu negara itu sendiri/ di luar negeri, meliputi tinggal untuk sementara waktu, dan mencari kepuasan yang beranekaragam dan berbeda dengan apa yang di alaminya dimana ia memperoleh pekerjaan tetap.

Menurut Yoeti (2001: 142) menjelaskan bahwa wisatawan merupakan seseorang yang melakukan perjalanan dari suatu tempat ke tempat lain atau ke suatu negara dengan bukan untuk tinggal permanen atau berbisnis, tetapi hanya bersenang-senang dan mengeluarkan uangnya di negeri yang dikunjungi, yang mana penghasilan tersebut diperolehnya bukan dari negeri yang dikunjungi, melainkan dari asalnya.

Menurut Chafid Fandeli (2000: 58), obyek wisata adalah perwujudan dari ciptaan manusia, tata hidup, seni budaya serta sejarah bangsa dan tempat ataukeadaan alam yang mempunyai daya tarik untuk dikunjungi wisatawan dan memiliki komponen yang harus ada untuk mendukung suatu daerah tujuan wisata yaitu:

1. Atraksi (Attraction), merupakan segala sesuatu yang menarik terdapat dilihat oleh wisatawan dan dinikmati saat berkunjung ke objek wisata.

2. Fasilitas (Aminities), merupakan segala sesuatu yang terdapat di objek wisata yang mampu menunjang kebutuhan wisatawan seperti: restaurant, Money Changer, Hotel, dan lain sebagainya.

3. Aksesibilitas (Accsess), merupakan penghubung wisatawan dalam menjangkau objek wisata, seperti: transportasi, jalan, dan pintu masuk lainya.

4. Pelayanan tambahan (Ancillary Service) merupakan pelayanan yang diperoleh saat berkunjung ke objek wisata seperti: seperti pelayanan dalam memberikan keamanan saat melakukan perjalanan wisata ke objek wisata, serta pelayanan sambutan ke objek wisata saat melakukan kunjungan.

Menurut Mulyana, (2010:179) menyatakan bahwa persepsi adalah sutau proses dalam diri manusia yang memungkinkan memiliki kemampuan dalam memilih, mengorganisasikan, dan menafsirkan rangsangan dari lingkungan sekitar, dan proses tersebut mempengaruhi prilaku individual. Menurut Rangkuti (2003: 31) makna dari persepsi dipengaruhi oleh pengalaman masa lalu dari individu yang bersangkutan, selain itu juga ada tiga faktor yang dapat memberikan pengaruh terhadap persepsi pelanggan terhadap produk ataupun jasa diantaranya:

1. Tingkat kepentingan pelanggan, yang didefinisikan sebagai keyakinan pelanggan sebelum mencoba atau membeli produk atau jasa yang dijadikan sebagai standar acuan dalam menilai kinerja produk atau jasa tersebut. Ada dua tonggak kepentingan 
pelanggan yang di antaranya adequate service (kinerja jasa minimal) dan service (kinerja jasa yang diharapkan).

2. Kepuasan pelanggan, yang didefinisikan sebagai jawaban konsumen terhadap ketidaksesuaian antara tingkat kepentingan sebelumnya dan kinerja yang dirasakanya setelah penggunaan. Faktor yang dapat mempengaruhi kepuasan pelanggan salah satunya adalah persepsi pelanggan mengenai kualitas jasa yang berfokus pada lima dimensi jasa.

3. Nilai, yang didefinisikan sebagai pengkajian secara menyeluruh manfaat dari suatu produk, yang didasarkan pada persepsi pelanggan atas apa yang telah diterimanya terhadap produk atau jasa yang diberikan.

Menurut Black (1981: 18) aksesibilitas adalah suatu ukuran kenyamanan atau kemudahan lokasi tata guna lahan berinteraksi satu sama lain, dan mudah atau sulitnya lokasi tersebut dicapai melalui transportasi. Aksesibilitas yang mampu memberikan dukungan dalam kegiatan pariwisata terdapat dua jenis aksesibilitas yang terdiri dari:

1. Aksesibilitas internal yaitu suatu proses dalam pencapaian tempat atau lokasi objek wisata dalam lingkup lokal yang merupakan faktor ketersediaan untuk melayani wisatawan dari dalam kota.

2. Aksesibilitas Eksternal yaitu suatu proses pencapaian objek wisata ataupun tujuan wisata yang menghubungkan antar kota.

Menurut Salim (1993:6) menyebutkan bahwa transportasi adalah kegiatan pemindahan barang (muatan atau penumpang dari suatu tempat ke tempat yang lain) dalam transportasi terlihat ada dua unsur yang terpenting yaitu: pemindahan/ pergerakan, Secara fisik mengubah tempat dari barang dan seseorang ke tempat lain

\section{METODE PENELITIAN}

Penelitian ini mengambil lokasi di Toyo Bungkah yang termasuk wilayah Desa Batur yang terletak di kaki Gunung Batur atau dipinggir Barat Danau Batur.Tujuan dari penelitian untuk mengetahui persepsi terhadap aksesibilitas yang dilalui oleh wisatawan selama melakukan perjalanan menuju Toya Bungkah di Desa Batur serta upaya perbaikan atau proses maupun langkah yang dilakukan oleh pihak pengelola untuk meningkatkan kualitas serta kondisi aksesibilitas.

Penelitian ini menggunakan teknik pengumpulan data dengan observasi, wawancara, kuesioner, studi kepustakaan. Teknik pengambilan sampel mengunakan Quota Sampling dengan mengambil sampel sebanyak 50 orang responden. Metode analisis data dalam penelitian ini yaitu metode analisis data deskriptif kualitatif dan digunakan pengukuran skala likert dengan masing-masing bobot yang berbeda yang diantaranya: Sangat baik (Very good) memiliki bobot nilai 5, baik (Good) memiliki bobot nilai 4, cukup baik (Good enough) memiliki bobot nilai 3, tidak baik (Bad) memiliki bobot nilai 2 dan sangat tidak baik (Poor) memiliki bobot nilai 1 .

\section{HASIL DAN PEMBAHASAN \\ Karakteristik Wisatawan}

Karakteristik wisatawan berdasarkan umur yang berkunjung atau melewati aksesibilitas Toya Bungkah wisatawan yang berumur 21 - 40 tahun mendominasi kunjungan sebesar 28 orang atau $56 \%$, berdasarkan jenis wisatawanya yang mendominasi adalah wisatawan mancanegara sebesar 32 orang atau 64 persen, karakteristik wisatawan berdasarkan jenis kelamin yang mendominasi ialah jenis kelamin laki-laki sebesar 27 orang atau $54 \%$. Karakteristik jumlah frekuensi kunjungan yang mendominasi adalah berfrekuensi sekali sebesar 25 orang atau 50 persen, karakteristik wisatawan berdasarkan asal informasi mengenai Toya Bungkah didominasi oleh informasi dari Internet sebanyak 28 orang atau 56 persen, karakteristik wisatawan berdasarkan jenis transportasi yang digunakan didominasi oleh Sepeda motor sebanyak 15 0rang atau $30 \%$.

\section{Jenis dan Macam Sarana Transportasi Pada Jalur Wisata Toya Bungkah}

Sarana transportasi yang ada di kawasan Toya Bungkah adalah sarana transportasi darat dan saranan tranportasi yang ada di danau. Transportasi tersebut memiliki peranan yang berbeda pada kehidupan masyarakat setempat, adapun sarana transportasi yang ada pada Toya 
Bungkah di bagi menjadi 2 jenis angkutan antara lain:

1. Sepeda motor

2. Sepeda

3. Mobil (Truk, Pick up, Public Transport dan Shuttle Bus)

4. Angkutan danau atau angkutan perairan

5. Perahu kayu

6. Boat yang ada di Danau

Persepsi Wisatawan terhadap Aksesibilitas yang Dilalui Dari Penelokan Menuju Daya Tarik Wisata Toya Bungkah

Persepsi terhadap aksesibilitas menuju objek wisata Toya Bungkah sangat besar pengaruhnya terhadap pengembangan dalam pengelolaan daya tarik wisata Toya Bungkah. Berdasarkan hasil penelitian yang telah dilakukan dapat diketahui bahwa persepsi wisatawan terhadap kondisi aksesibilitas yang dilalui oleh wisatawan dari Penelokan mendapat skor rata-rata 3,10 yang berarti cukup baik, kualitas aksesibilitas yang dilalui wisatawan mendapatkan skor rata-rata 3,20 yang berarti cukup baik, tingkat kenyamanan wisatawan saat melalui aksesibilitas dari Penelokan menuju Toya Bungkah mendapatkan skor rata-rata 3,14 yang berarti cukup baik, kondisi transportasi setelah melalui aksesibilitas dari Penelokan menuju Toya Bungkah mendapatakan skor ratarata 3,48 yang berarti baik, pemandangan pada sekitar aksesibilitas yang dilihat wisatawan selama menuju objek wisata Toya Bungkah dari Penelokan mendapatkan skor rata-rata 4,08 yang berarti baik, tingkat keselamatan wisatawan selama melewati aksesibilitas dari Penelokan menuju Toya Bungkah mendapatkan skor ratarata 3,50 yang berarti baik dan persepsi wisatawan terhadap objek wisata Toya Bungkah mendapatkan skor rata-rata 3,76 yang berarti baik. Skor rata-rata daripada total jawaban responden yaitu 24,26:7=3,46 (baik). Hasil tersebut menunjukan bahwa persepsi wisatawan terhadap aksesibilitas dari penelokan menuju objek wisata Toya Bungkah Kecamatan Kintamani Kabupaten Bangli memperoleh tanggapan baik dari wisatawan. Sehingga wisatawan yang melakukan perjalanan menuju objek wisata Toya Bungkah masih mampu melewati aksesibilitas dari Penelokan, walaupun diperlukanya pembenahan lebih lanjut terhadap kondisi dan kualitas aksesibilitas di Toya Bungkah untuk keamanan dalam melakukan perjalanan.

Usaha Yang Dilakukan dalam Pembenahan Aksesibilitas oleh Pihak Pengelola Obyek Wisata Toya Bungkah

Aksesibilitas di Toya Bungkah penting untuk diperhatikan, hal tersebut dikarenakan aksesibilitas memberikan pengaruh yang cukup besar terhadap kunjungan wisatawan terutama yang berkunjung untuk menikmati suasana alam Gunung Batur serta Toya Bungkah pada umumnya. Hasil observasi yang telah dilakukan dapat dilihat bahwa, masih banyak jalur aksesibilitas yang berlobang dan jalurnya masih terbilang sempit. Hasil wawancara juga menyebutkan adanya ketidak teraturan antar penggali pasir dalam melakukan pekerjaanya, sehingga perlu kiranya adanya pembenahan bila adanya kerusakan. Adapun usaha-usaha yang dilakukan oleh pihak-pihak pengelola dalam memperbaiki aksesibilitas dari Penelokan menuju objek wisata Toya Bungkah ialah:

1. Memberikan usulan kepada pihak pemda setempat untuk dibuatkanya lampu pada sekitaran aksesibilitas menuju Toya Bungkah.

2. Melakuakan perjanjian pada pihak-pihak galian truk terhadap waktu dalam melakukan pekerjaanya.

3. Membuat jaringan aksesibilitas

\section{SIMPULAN DAN SARAN Simpulan}

Persepsi terhadap aksesibilitas yang dilalui wisatawan dari Penelokan menuju objek wisata Toya Bungkah adalah baik dengan skor rata-rata dari total jawaban responden yaitu 3,46 (baik). Usaha-usaha yang dilakukan guna pembenahan aksesibilitas oleh pihak pengelola objek wisata toya bungkah ialah diantaranya: Memberikan usulan kepada pihak Pemda untuk dibuatkanya lampu pada sekitaran aksesibilitas menuju Toya Bungkah. Melakukan perjanjian pada pihak-pihak galian truk terhadap waktu dalam melakukan pekerjaan, membuat jaringan aksesibilitas. 


\section{Saran}

Saran yang dapat diajukan bagi pihak pengelola objek wisata Toya Bungkah terkait dengan Aksesibilitas adalah sebagai berikut:

1. Hendaknya melakukan kerjasama dengan penduduk setempat guna mengontrol aksesibilitas bila adanya kerusakan.

2. Hendaknya memperbaiki kondisi aksesibilitas menuju Toya Bungkah dengan melakukan kerjasama dengan Pemda setempat.

3. Pengelola Toya Bungkah hendaknya meningkatkan kualitas aksesibilitas untuk memperlebar jalur saat melakukan perbaikan aksesibilitas dari Penelokan menuju Toya Bungkah.

\section{DAFTAR PUSTAKA}

Black, Jhon. 1981. Urban Transport Planning, $3^{\text {rd }}$ edition. Hutchinson, Melbourne.

Dinas Pariwisata Kabupaten Bangli. 2011. Pengembangan Objek Dan Daya Tarik
Wisata Kabupaten Bangli. Bangli: Dinas Pariwisata Kabupaten Bangli.

Fandeli. Chafid.2001. Dasar-dasar Manajemen Kepariwisataan Alam. Yogyakarta: Graha Ilmu.

Mulyana, Deddy. 2010. Ilmu Komunikasi Suatu Pengantar. Bandung: PT. Remaja Rosdakarya.

Rangkuti, Freddy. 2003. Measuring Customer Satisfaction, Gaining Customer Relationship Strategy, Jakarta: PT Gramedia Pustaka Utama. Libert

Salim, H.A Abbas. 1993. Manajemen Transportasi. Jakarta: PT. Raja Grafindo Persada.

Yoeti Oka A. 1997. Perencanaan dan Pengembangan Pariwisata. PT. Pradnya Paramita.

.2001. Tours And Travel Manajement. Jakarta: Pradnya Paramita. 